\title{
America's Hong Kong Policies and Recent Political Trends
}

\author{
Xiaowei Yuan \\ Master of Laws, Law school \\ Guangdong University of Foreign Studies \\ Higher Education Mega Center, Panyu District, Guangzhou City, Guangdong Province, China
}

\author{
Yujue Peng \\ School of Government and Public Policies \\ University of Strathclyde \\ Glasgow, Scotland, U.K
}

\author{
Xiaocong Yuan \\ Master of Laws, Law school \\ Guangdong University of Foreign Studies \\ Higher Education Mega Center, Panyu District, Guangzhou \\ City, Guangdong Province, China
}

\author{
Shenglong Jiang \\ Law school \\ Guangdong University of Foreign Studies \\ Higher Education Mega Center, Panyu District, Guangzhou \\ City, Guangdong Province, China

Zehua Feng
Master of Laws, Law School and Intellectual Property
School
Jinan University
No.601, Huangpu West Rd, Guangzhou, China 510632

"Arbitration between the Republic of the Philippines and the People's Republic of China". In Cross-Strait relation, Tsai lng-wen, a pro-America and new president of Taiwan, takes office in recent days. America may have an opportunity to trigger ensign in cross-Strain relation to restrict the growing mainland China. In economic area, America is promoting the Trans-Pacific Partnership (TPP) to enhance trading relations with Asian and Pacific countries; in security, America modulates and strengthens her military power base in AsiaPacific area. Hence we can see that the United State is working hard to restrict the growing China in issues of the East China Sea, of South China Sea and of Taiwan in political, economic and security areas. In the long run, such restriction trend will further enhance the strategical competition between America and China. In this sense, Hong Kong is becoming an important element, thus, new trends has emerged in America' Hong Kong polities.

\section{RECENT AMERICA's Hong Kong POLICIES AND NEW TRENDS}

\section{INTRODUCTION}

In 2009, the United States officially announced the "Asia-Pacific Rebalance". This strategy aims to contain the growing China and maintain U.S. global leadership. In recent years, the Untied States has worked actively to solidify and enhance its relations with existing Asian and Pacific partners. The U.S. supports Japan's exclusion of collective selfdefence right in order to "use Japan to contain China". In South China Sea issue, the U.S dispatched patrol boats to patrol the South China Sea under the name of "Freedom of Navigation". It showed her support to Philippines on the

\section{A. Pay Strict Attention to Hong Kong}

In 2013, Clifford Hart, US Hong Kong Consul General, officially encouraged the Democrats to participate the 2017 General Election and advocated Hong Kong to achieve a "genuine universal suffrage" ${ }^{[1]}$. In 2014, Daniel Russel, US Assistant Secretary of State announced that the United States support a "genuine universal suffrage". As to the "Occupy Central" issue, America did not present her support publicly. Obama, the American Present, announced that the United State did not support the protest and John Kerry, the Secretary of State, recently involved the Hong Kong 
authority to restrict demonstrators. This evidence implies that America supports the "Beijing-opposite parties" but is reluctant to stand with them on public stage.

\section{B. Keep in Touch with "Hong Kong Independence" Forces and Secretly Offer Financial Support}

After the failure of policy reform, "Hong Kong independence forces" have increased. They set up political parties and issued a "referendum on self-determination". Additionally, the "local democracy frontline" will take part in the Legislative Council Election this September. America shows high levels of interest in these issues. On 9 March 2016, US consular officials in Hong Kong met the "local democracy frontline" members Ray Wong and Edward Leung (Tin-kei). During the meeting, America indicated that she would not openly support violent protest, but she did feel sympathy and understanding towards the violent behaviours of "Hong Kong independence". America hoped the local democracy frontline members could report to the American embassy before they created the future violent issues such as the "Mong Kok Riots". In doing so, the American government would be able to "keep abreast of the updates" and "offer guidance". American officers also indicated that the America government could offer financial support via the National Endowment for Democracy ${ }^{[2]}$.

\section{Increase attention to Human Rights, Freedom Of Speech and Press}

American authorities and private sectors have long been concerned the human rights and freedom of speech and press in Hong Kong, and such concern have been increasing in recent years. In 2015, the U.S. State Department issued "U.S. -Hong Kong Policy Act Report", together with "China Human Rights Report", focusing on the freedom of speech in Hong Kong; in the annual reports from the U.S. Congressional-Executive Commission on China (CECC) and US-China Economic and Security Review Commission (USCC), the narrow freedom of press and public media has been highly emphasised. The annual report of USCC covers 28 pages and announces that Hong Kong is facing challenges in its high degree of autonomy. The freedom of speech, press and academy, in particular, are now under a new political pressure. In this report, the USCC suggested the United State to enhance public relations with Hong Kong, to re-examine the "U.S.-Hong Kong Policy Act Report" and to regularly report their practice to the Congress. Besides, they also advised the U.K and the U.S should cooperate together in order to conduct joint-investigation on the current statement of Chinese government's operation on "the Basic Law".

Furthermore, in 2014 and 2015, members of both parties in US Congress issued two drafts of Hong Kong human rights and democracy act. These drafts require the relevant parties to update the "1992 US-Hong Kong Act"and to reinstate the Article 301. At the same time, those drafts also require the US Secretary of State to assess and verify the current level of autonomy in Hong Kong, and based on the assessment, they would decide whether to continue the "1992 US-Hong Kong Act".

\section{Increase Intervention on Hong Kong Issues}

After the announcement of "Asia-Pacific Rebalance" strategy, the visits from American officers are enhanced in terms of frequency and deepened in political level. From 2011 to 2013, there were a total of five ministers, including the Secretary Hillary Clinton, and several deputy ministers that have visited Hong Kong. Secretary Clinton has been the highest level official who visited Hong Kong since the Hongkong back to China. Since then, although there have not been any higher level American officials to visit Hong Kong, the importance of Hong Kong affairs are announced up to the vice presidential and even presidential level.

In April 2014, Joe Biden, the Vice President, "encountered" Martin Lee (Chu-ming) and Anson Chan (Fang On-sang) and acknowledged the current situation of Hong Kong. On 2 October, the Secretary Clinton expressed her support on the general election and required Hong Kong government to keep restrictions on the "Occupy Central" action. In November, during the APEC Summit, Obama announced that America was not involved in Hong Kong "Occupy Central" activities. However, he indicated that American foreign policy and its value is to constantly support people to present their own voice, to encourage a transparent and fair Hong Kong election, and to make sure the election reflected the voice of the average Hong Kong citizen. It is clear that USA interfere in the internal affairs of Hongkong.

\section{CHANNEls AND Methods}

Channels and methods of U.S intervention on Hong Kong affairs are as follows:

\section{A. Two Channels}

America interferes in Hong Kong affairs mainly on two channels: official and non-governmental organisations. These two channels combine together and generate a wellrounded and multi-level system, which operates on high concealment. The official channel includes open speeches from senior officials; political agenda discussions between American and Chinese leaders; declarations from the State Council and the American embassy in Hong Kong; Hong Kong related reports form the State Council and the Congress. Non-governmental sector consists of two major promoting forces, namely "National Endowment for Democracy" and "National Democratic Institute".

\section{B. Four Methods}

In September 2011, "WikiLeaks" exposed thousands of classified and confidential messages from the Consulate General of the United States in Hong Kong. Those messages reveal the major methods of how America interferes in Hong Kong affairs, which are as follows:

1) Put pressure on Hong Kong SAR officials: When meeting Hong Kong officials, American officials collect SAR officials' opinions on specific political agendas and further, they indicate the American position on those issues in order to put pressure on those relative Hong Kong 
officials. In July 2009, Joseph R. Donovan Jr, the U.S Consul General, expressed America's position on Hong Kong political reform to Jasper Tsang Yok-sing, the Chairman of the Hong Kong Legislative Council during the farewell party and expressed America's opposition on delaying political reform. In May 2014, Daniel R. Russel, the American Assistant Secretary of State, visited Hong Kong. When he met the Hong Kong officials, he expressed America's position of supporting a "real general election".

2) Select political agents: America keeps regular meeting with Pan-Democratic to collect information and looking for political agents to get involved in "Pandemocratic Camp" and domestic affairs. Officials from the American consulate have regular meeting with anti-Beijing party members Jimmy Lai (Chee-ying), Joseph Zen (zekium), Anson Chan (Fang On-sang) and Allen Lee (Pengfei). In 2007, America helped Jimmy Lai, Joseph Zen, Anson Chan and Allen Lee to form a "four-person gang", and these four persons became the key members in conducting the illegal "Occupy Central" movements. Recently, the US embassy contacted "Hong Kong proindependence". Their discussions include the pandemocratic camp's opinions on various political agendas, financial bailout, election strategies, etc. In addition, America canvassed for the "pan-democratic camp". In October 2007, when the then-member of Legislative Council, Martin Lee (Chu-ming) visited America, Hong Kong was holding District Council Election and by-election on seats in the Legislative Council. The campaign was between Regina Ip (Lau Suk-yee), the representative of Pan-establishment Camp and Anson Chan, the representative of Pan-democratic Camp. The massages from the American embassy believed that Anson Chan's election was under the persuasion of Martin Lee, and at that time, Martin Lee was critiquing China's policies towards Hong Kong, which was believed to solicit votes for Anson Chan. Thus, American authorities organized discussions on the situation of Hong Kong's political development with both US State Department and National Security Council and finally, Anson Chan won the election.

3) Publish reports to promote "internationalized" Hong Kong issues: Both official and private sectors, including US State Department, CECC, USCC and National Democratic Institute (NDI), publish Hong Kong related reports to push Hong Kong issues to become "internationalized", to enhance their influential power and thereby, provoking public pressure on Chinese government.

4) Finance Hong Kong research projects, shape relative seminars and workshops and train social movements leaders: American non-governmental organisations such as National Endowment for Democracy (NED), National Democratic Institute (NDI) and other non-governmental organisations were found financially supporting Hong Kong Pan-democratic Camp in forms of political donation and project funding. These groups work to promote political strategies via academic seminars and workshops in order to cultivate movement leaders. More importantly, American non-governmental organisations strengthen their influence on Hong Kong colleges and universities with research projects under various names. These research projects create training platforms for pan-democratic parties to study specific political strategies and to train movement leaders, and at the same time, those researches help to advocate political norms of Pan-democratic Camp. During the years 2012-2014, the American non-governmental organisations, National Democratic Institute, has subsidised 630,000 Hong Kong dollars to the Comparative and Public Law Centre at the Faculty of Law in the University of Hong Kong, 66,000 Hong Kong dollars to Public Opinion Programme in the University of Hong Kong and 5,000 Hong Kong dollars to the Kadoorie Institute in the University of Hong Kong. Those funds were used mainly on specific "democracy" related researches. Within those research institutes, the Comparative and Public Law Centre launched a website "Designdemocracy.hk". This website performed actively during "Occupy Central" activities, including suggesting the activity leaders to use "Firechat" as communication application, providing shopping address for gas masks, advising protesters to throw away sharp objects to avoid being sued for having offensive weapons, and offering them response guidance and lawyers' contacts information in case of being arrested ${ }^{[3]}$.

\section{INCENTIVES OF AMERICA's INTERFERENCE IN HONG KONG AFFAIRS}

\section{A. Huge Economic Benefit}

Enormous economic benefits are the main reason why America pays strong attention to Hong Kong issues. By 2014, America is the second largest trading partner and the fifth products supplier of Hong Kong. There were more than 1,300 business projects operating in Hong Kong. According to 2014 statistics, there are about 65,000 American citizens settled in Hong Kong and in total, more than one million American citizens have visited or transited in Hong Kong. In 2014, the value of American export goods to Hong Kong was around 28 billion, consisting $5 \%$ of the total import value to Hong Kong. Hong Kong has become the ninth export market for American industrial products, the sixth agricultural export market. Specifically, the number one in nut products, the forth in beef products and also the forth in alcoholic products ${ }^{[4]}$. Meanwhile, American government believes that " U.S interests are enhanced by Hong Kong's continued autonomy, stability, and prosperity; protection of civil liberties; and the preservation of Hong Kong's respect for the rule of law under 'one country, two systems"'(Hong Kong Policy Act Report, April 10, 2015). Therefore, America follows Hong Kong political development closely in order to protect its own interests. 


\section{B. Creating "Democracy Showcase"}

Mainland China and Hong Kong have geographical proximity and similarities in culture and language. Besides, the increasing communication and exchange between mainland China and Hong Kong and the reunification of Hong Kong provides a perfect "springboard" for America to get involve in Chinese domestic affairs. America aims to build Hong Kong as a "democracy showcase" to promote western democratic regimes, so as to attract mainland followers and thereby, subverting the political system in mainland China. In 2014, after the breakup of "Occupy Central", Josh Earnest, the current White House Press Secretary, officially announced that the White House expected that Hong Kong's democratic ideology could be able to transfer to mainland China ${ }^{[5]}$.

\section{Solid "Asia-Pacific Rebalance” Strategy to Contain China}

America's Hong Kong policy, according to America government's foreign agenda, belongs to Sino-US relations. Currently, with the intensifying strategical completion between America and China, Hong Kong's political and financial positions in Asia-Pacific region have a dramatic impact on Chinese finance reform and RMB internationalisation. Therefore, if America interferes in Hong Kong issues, it could potentially constrain the Chinese development. Additionally, the special political and economic position of Hong Kong provides opportunity for American interference.

\section{To Satisfy Military Supply Needs}

Famous as "shopping haven", Hong Kong enjoys natural deep water ports, excellent and professional marine services. Hence, American Navy Fleets often rest and gain supplies in Hong Kong. Within three years, from 2013 to 2015, 13 African vessels, on average, visit Hong Kong every year. ${ }^{[6]}$

\section{CONCLUSION}

\section{A. The Prospects of U.S. Hong Kong Policy}

In present, America's Hong Kong policies continue the tone of "1992 United States-Hong Kong Policy Act". America recognises "Joint Declaration of the Government of the United Kingdom of Great Britain and Northern Ireland and the Government of the People's Republic of China on the Question of Hong Kong" and accepts "one country, two systems". However, "Asian-Pacific Rebalance" provides intensifying America-China strategical competition, and conflicts in the South China Sea and cyber security have stressed in a higher level. Under this background, America may attempt to undermine Chinese governmental administration tactics towards Hong Kong and force China to make concessions in other agendas. Moreover, Hong Kong's political ecology is experiencing reshuffle after the failure of political reform, which offers opportunity for America to lend a hand on Hong Kong affairs. In the coming future, America's interest in Hong Kong issues will extent in range and enhance in depth.
“1992 United States-Hong Kong Policy Act" remains the foundation of U.S-Hong Kong Policy

According to this Act, America should play an active role after Hong Kong's reunification to maintain the credit and prosperity of Hong Kong and to protect the financially central position of Hong Kong ${ }^{[7]}$. Because Hong Kong and America share massive and close economic and trading exchanges, maintaining Hong Kong's stability and prosperity is of beneficial for American economic interest. Therefore, America is reluctant to witness large-scale social unrest in Hong Kong, and is willing to make sure Hong Kong hold the current political and economic system. In this sense, although America was the wire-puller under the "Occupy Central" protect, she also repeatedly emphasised on rejection of violence. When America saw the "Occupy Central" protects was nearly out of control, she suggested them to retreat. Therefore, America supports the general election of Hong Kong, and encourages larger range of more press and speech freedom in Hong Kong. The best way to protect America's interest in Hong Kong is to reform Hong Kong's political system until it becomes a complete western democracy model.

Under the framework of "1992 United States-Hong Kong Policy Act”, US State Department will publish Hong Kong report in an irregular base. When necessary, America could reset the Article 301 to guarantee regular reports. What is more, this Act functions on the basis of principles in "SinoBritish Joint Declaration". However, recently, some Hong Kong citizens argue that "Sino-US Joint Statement" and "The Basic Law of Hong Kong" have been undermined. Therefore, in the future, America may ally with Britain to conduct "co-supervision" on Chinese practice of "SinoBritish Joint Declaration". Especially, the annual report of U.S.-China Economic and Security Review Commission (USCC) suggested Britain and America should joint together to investigate the current implementation of the "Hong Kong Basic Law".

\section{B. Weaken and Undermine Chinese Central Government Control and Influence Power over Hong Kong}

While holding the general stable society in Hong Kong, in the future, America will continually penetrate her influence into the development of Hong Kong civil society with non-governmental organisations. In finance, America will support Hong Kong Pan-democratic Camp with political donations and project fundings, which will contribute to the promotion of struggle strategies and to train social movement leaders in forms of workshops and seminars. In politics, officials in US Consulate General in Hong Kong will remain regular contact with pan-democrat to give guidance on principles and election strategies. Most importantly, America contacts with "Hong Kong independent" forces, and recently, presents her willingness of financial aid via non-governmental organisations and even inviting "Hong Kong independent" members to America. A new round of Hong Kong Legislative Council Election will be held this September. America will most likely support the "Hong Kong independent" forces to participate the general election. If these forces fail to enter Legislative Council, 
America would "command" them to initiate street fight in order to coordinate the actions of Pan-democratic Camp and further, to pressure Chinese central government and Hong Kong authorities. Furthermore, the penetration projects in Hong Kong colleges and universities are proved a fruitful outcome during the "Occupy Central" protect. In the future, America may reinforce those efforts. Besides funding university "research project", America will also finance university clubs and journals to carry out exchange activities.

\section{Use Hong Kong to Influence Sino-US Relations and to Contain China}

Hong Kong US relations are part of Sino-US relations. America proposes "Asia-Pacific Rebalance" strategy to restrict the growing China. However, because Chinese government has insisted in its political position and American alliance is comparatively weak, China and America are in the opposition position in several political agendas, such as South China Sea issues. In this background, America may utilise Hong Kong issues to contain China and to serve its "Asia-Pacific Rebalance" strategy. But on the other side, an unstable Hong Kong may threaten the enormous economic benefits for America, and what is worse, that may not contribute to generating "democracy showcase" to alter Chinese political system. Additionally, if social turmoil occurs in Hong Kong, that may fail to solidify the "Asia-Pacific Rebalance" strategy. To sum up, America will utilise adequate and appropriate tactics to interfere in Hong Kong issues in order to contain China. Those interference instruments prone to be open and published, including encourage the Pan-democratic Camp to conduct street fights, with the bottom line that Hong Kong could not be involved in large-scale social turmoil and fundamental changes.

\section{REFERENCES}

[1] Pingli Wen, "The quiet revolution of Xia Qianfu is full of danger", in press.

[2] Xue Ma, "U. S. consulate officials Keep in touch with local democracy frontline", in press.

[3] Qiangguo Xian, "NDI try to launch revolution in Hongkong”, in press.

[4] Bureau of East Asian and Pacific Affairs,"Hong Kong Policy Act Report" April 10, 2015, available at www.state.gov/p/eap/rls/reports/2015/240585.htm, access on May 2016.

[5] Mark Landler, "The United States do not want to conflict with China for Hongkong", in press.

[6] Bureau of East Asian and Pacific Affairs, "Hong Kong Policy Act Report" April 10, 2015, available at www.state.gov/p/eap/rls/reports/2015/240585.htm, access on May 2016.

[7] Consulate General of the United State, "United States-Hong Kong Policy Act of 1992", available at http://hongkong.usconsulate.gov/ushk_pa_1992.htm, access on May 2016. 